\title{
Membranes obtained on the basis of cellulose acetate and their use in removal of metal ions from liquid phase
}

\author{
Joanna Krason, Robert Pietrzak* \\ Adam Mickiewicz University in Poznań, Faculty of Chemistry, Laboratory of Applied Chemistry, Umultowska 89b, \\ 61-614 Poznań, Poland \\ "Corresponding author: e-mail: pietrob@amu.edu.pl
}

\begin{abstract}
The polymer membranes containing $18 \mathrm{wt} \%$ of cellulose acetate and different amounts of polyvinylpyrrolidone (PVP) as a cross-linker agent were used in the process of iron and copper ions removal from liquid phase. Depending on the content of PVP (changed from 1 to $4 \mathrm{wt} . \%$ ) the membrane surfaces were characterised by different hydrophilic character and showed the dominant presence of surface oxygen-containing groups of acidic character. Irrespectively of the concentrations of solvents from which the metal ions had to be removed, the membranes showed better ability to remove $\mathrm{Fe}^{3+}$ ions than $\mathrm{Cu}^{2+}$ ones, and the membrane resistances decreased with increasing content of PVP. After the filtrations of solutions with iron ions the flux recovery ratio took rather high values; this ratio increased with increasing PVP content in the membrane.
\end{abstract}

Keywords: cellulose acetate membrane, phase inversion, physical and chemical properties, $\mathrm{Cu}$ and $\mathrm{Fe}$ ions removal.

\section{INTRODUCTION}

An important problem of our times that needs urgent and coordinated solution is increasing pollution of the natural environment. Until recently people have not been aware of the scale of degradation caused by modern technologies leading to poisoning of water, soil and air ${ }^{1-3}$. Particularly dangerous is the presence of post-production waste in water, as it affects not only plants and animals but is also hazardous for health and life of people ${ }^{4-6}$. Since the danger was realised, much effort has been devoted to improve the technologies and to finding effective methods for the separation of pollutants from liquid phase. The methods proposed for this purpose include removal on block copolymers, flocculation, adsorption on activated carbons and carbon nanotubes, membrane methods of separation, including the method of separation under pressure $^{7-15}$. From among many methods proposed, the use of membranes has enjoyed particular interest because of the low cost and simple application and these methods have been increasingly used for removal of different kind pollutants ${ }^{16,17}$. Depending on the type of pollutant to be removed (metal ions, proteins, emulsions, dyes), different pore size membranes are used and according to the size pores the filtration methods have been divided into microfiltration, ultrafiltration, nanofiltration and reversed osmosis ${ }^{18-22}$.

The membranes used in the pressure methods of separation are obtained in the processes of phase inversion, sintering and stretching of polymer films ${ }^{23-25}$. The process of phase inversion is commonly used for the preparation of membranes from polymers such as poly(vinyl alcohol), polyethersulfone, polypropylene or cellulose acetate ${ }^{26-29}$. A mixture of a polymer, non-solvent and solvent is spread over glass, the solvent is evaporated and the mixture on the glass is immersed in the coagulation bath. As a result asymmetric porous membranes are obtained ${ }^{30-32}$. An often met problem is the presence of iron and copper ions in water. Too high content of these ions in human organisms is associated with cancer, nervous system disturbances, cardiovascular conditions and metabolic problems ${ }^{33-36}$.
This paper reports results of a study on characterisation and performance (in removal of iron and copper ions) of membranes obtained on the basis of cellulose acetate. The membranes studied differed in the content of polyvinylpyrrolidone used the cross-linker polymer.

\section{EXPERIMENTAL}

\section{Material}

Cellulose acetate (CA) was purchased from Sigma Aldrich and used as a membrane material. $N, N$-dimethyloformamide (DMF) was purchased from POCh and used as a solvent. Polyvinylpyrrolidone (PVP, $10000 \mathrm{~g} /$ mol) as a pore former was supplied by Sigma Aldrich.

\section{Preparation of CA membranes}

Casting solutions of CA $18 \mathrm{wt} . \%$ and 1, 2, 3 or $4 \mathrm{wt} . \%$ of PVP were prepared by mixing the ingredients in a flask. The casting solution obtained was left to rest for about $24 \mathrm{~h}$ to allow complete release of bubbles. After that, it was cast onto a glass plate using a stainless-steel knife to get a casting film of $300 \mu \mathrm{m}$ thickness, exposed to the atmosphere for $40 \mathrm{~s}$, and then immersed into a coagulation bath of pure water. The as-prepared cast solution films were immersed and kept for $24 \mathrm{~h}$ in a deionised water bath conditioned at $25^{\circ} \mathrm{C}$ to complete the exchange between the solvent and non-solvent.

\section{Methods}

The membrane porosity was determined by the mass loss of wet membrane after drying. The membrane sample was mopped with water on the surface and weighed under wet status. Then, the membrane sample was dried until a constant mass. The membrane porosity $\varepsilon$ was evaluated from Eq. (1):

$\varepsilon=\frac{W_{w}-W_{d}}{\rho \cdot v} \cdot 100 \%$

where $\mathrm{W}_{\mathrm{w}}$ is the mass of a wet membrane sample, $\mathrm{W}_{\mathrm{d}}$ is the mass of dry state membrane sample; @ pure water density and $\mathrm{v}-$ is the volume of a membrane in wet state. 
The equilibrium water content (EWC) was determined by Eq. (2):

$E W C=\frac{W_{w}-W_{d}}{W_{w}} \cdot 100 \%$

The contact angle between water and membrane was directly measured using a contact angle measuring instrument G10, KRUSS, Germany. For evaluation of the membrane hydrophilicity deionized water was used as a probe liquid in all measurements. To minimize the experimental error, the contact angle was measured at five random locations for each sample and then the average was reported.

The surface properties were characterised using potentiometric titration experiments using 809 Titrando equipment manufactured by Metrohm. The instrument was set at the mode when the equilibrium $\mathrm{pH}$ was collected. Materials studied in the amount of about $0.05 \mathrm{~g}$ in $50 \mathrm{~mL} 0.01 \mathrm{M} \mathrm{NaNO}_{3}$ were placed in a container thermostated at $25^{\circ} \mathrm{C}$ and equilibrated overnight with the electrolyte solution. To eliminate the influence of atmospheric $\mathrm{CO}_{2}$, the suspension was continuously saturated with $\mathrm{N}_{2}$. The suspension was stirred throughout the measurements. Volumetric standards $\mathrm{NaOH}(0.1 \mathrm{M})$ or $\mathrm{HCl}(0.1 \mathrm{M})$ were used as titrants ${ }^{37}$. Directly prior to use, each electrode was washed with a small amount of deionised water.

Water permeability of the membranes prepared was measured in a stainless steel cell, holding the effective membrane area of $19.6 \mathrm{~cm}^{2}$. The membranes were initially subjected to deionised water of 3 bar for about $1.5 \mathrm{~h}$ before testing. Then, the pure water flux was measured at 3 bar, $23 \pm 1^{\circ} \mathrm{C}$ and $0.22 \mathrm{~m} / \mathrm{s}$ cross-flow velocity. The pure water flux was calculated from the following equation:

$J_{w}=\frac{V}{A \cdot \Delta t}$

where: $\mathrm{J}_{\mathrm{w}}\left(\mathrm{L} /\left(\mathrm{m}^{2} \mathrm{~h}\right)\right)$ is the pure water flux, $\mathrm{V}(\mathrm{L})$ is the volume of permeated water, $\mathrm{A}\left(\mathrm{m}^{2}\right)$ is the effective membrane area and $\mathrm{Dt}(\mathrm{h})$ is the permeation time.

The experiments were conducted using compressed nitrogen gas and iron or copper solutions of different initial concentrations $(12$ or $20 \mathrm{mg} / \mathrm{L}$ for iron solution and 800 or $1000 \mathrm{mg} / \mathrm{L}$ for solution of copper) and all measurements were made at $3 \mathrm{bar}$, in triplicate. The final concentration of iron or copper in the solution was analysed using a double beam UV-Vis spectrophotometer (Varian Cary $100 \mathrm{Bio}$ ) at $487 \mathrm{~nm}$ wavelength for iron solutions and at $620 \mathrm{~nm}$ wavelength for copper solutions. The iron or copper rejections (\%R) were calculated from Eq. (4):

$\% R=\left(1-\frac{C_{p}}{C_{f}}\right) \cdot 100$

where $\mathrm{C}_{\mathrm{p}}$ and $\mathrm{C}_{\mathrm{f}}(\mathrm{mg} / \mathrm{mL})$ were iron or copper concentrations in the permeate and the feed solutions, respectively.

Membrane resistance was evaluated according to Darcy's law by the resistance in the series of models as follows:

$J=\frac{\Delta P}{\mu R_{t}}$ where $\mathrm{J}\left(\mathrm{L} /\left(\mathrm{m}^{2} \mathrm{~h}\right)\right)$ is the permeate flux, $\Delta \mathrm{P}$ is the transmembrane pressure (TMP), $\mu$ is the dynamic viscosity of permeate, and $\mathrm{R}_{\mathrm{t}}$ is the total filtration resistance. The resistance in the series of models combines various resistances causing flux decline as follows:

$R_{t}=R_{m}+R_{p}+R_{c}$

where, $\mathrm{R}_{\mathrm{t}}$ is the total filtration resistance composed of various resistances including that of the membrane itself $R_{m}$, pore blocking $R_{p}$, cake resistance $R_{c}$. The intrinsic membrane resistance $\left(R_{m}\right)$ can be estimated from the initial pure water flux (3). Fouling resistance $\left(R_{p}\right)$ is caused by pore plugging and irreversible adsorption of contaminants on membrane pore wall or surface. Cake resistance $\left(R_{c}\right)$ induced by cake layer formed on the membrane surface was calculated from the water flux after pure water washing ${ }^{38,39}$.

The detail membrane fouling behaviour was studied as follows. Firstly, pure water flux of the membrane $\mathrm{J}_{\mathrm{w} 1}\left(\mathrm{~L} /\left(\mathrm{m}^{2} \mathrm{~h}\right)\right)$ was tested at 3 bar. Then, aqueous solution of iron or copper $(12-1000 \mathrm{mg} / \mathrm{L})$ was fed into the ultrafiltration system. After filtration for $30 \mathrm{~min}$, the membrane was flushed with pure water for $10 \mathrm{~min}$ and then pure water flux of the membrane $J_{\mathrm{w} 2}\left(\mathrm{~L} /\left(\mathrm{m}^{2} \mathrm{~h}\right)\right)$ was measured. The flux recovery ratio (FRR) was calculated using Eq. (5) to evaluate membrane antifouling property:

$\operatorname{FRR}(\%)=\frac{J_{w 2}}{J_{w 1}} \cdot 100 \%$

\section{RESULTS AND DISCUSSION}

\section{Membrane characterisation}

The values of structural parameters and contact angles for the series of membranes studied are given in Table 1.

As follows from these data, the porosity of the membranes does not depend on the content of the cross-linker agent. The porosity values obtained for the membranes containing 1, 3, or 4 wt.\% PVP are similar and change from 43.55 to $44.54 \%$. For CA18 PVP2 the value of porosity is much higher, reaching $50.31 \%$. The values of equilibrium water content are similar for all membranes and change from 75 to $77 \%$. Difference between values of porosity and EWC follows fact that the pore distribution in the membrane is not symmetrical. Because of that values of porosity and equilibrium water content can sometimes differ. The contact angle measurements show that the membrane with a $3 \%$ content of PVP was characterised by the highest value of this parameter. For the other membranes the difference between values of contact angle is not significant and may be caused by roughness of membrane surface.

Table 1. Porosity $(\varepsilon)$, equilibrium water content (EWC) and contact angle of investigated membranes

\begin{tabular}{|l|c|c|c|}
\hline Membrane & $\varepsilon[\%]$ & EWC [\%] & Contact angle \\
\hline CA18 PVP1 & 44.13 & 75.57 & $61.9 \pm 2.41$ \\
\hline CA18 PVP2 & 50.31 & 76.74 & $62.8 \pm 1.47$ \\
\hline CA18 PVP3 & 43.55 & 76.93 & $58.0 \pm 3.43$ \\
\hline CA18 PVP4 & 44.54 & 76.89 & $61.1 \pm 3.08$ \\
\hline
\end{tabular}

\section{Membrane performance}

Tables 2 and 3 present the contents oxygen-containing acidic and basic groups on the surfaces of the mem- 
Table 2. Content of acidic surface sites on investigated membranes before and after filtration with $20 \mathrm{mg} / \mathrm{L}$ iron solution [mmol/g]

\begin{tabular}{|c|c|c|c|c|c|c|c|c|c|c|c|c|c|c|c|c|}
\hline \multirow{3}{*}{ Membrane } & \multicolumn{12}{|c|}{$\mathrm{pH}$} & \multirow{2}{*}{\multicolumn{2}{|c|}{$\begin{array}{l}\text { Acidic } \\
\text { groups }\end{array}$}} & \multirow{2}{*}{\multicolumn{2}{|c|}{$\begin{array}{l}\text { Oxygen-containing } \\
\text { groups }\end{array}$}} \\
\hline & \multicolumn{2}{|c|}{$<3$} & \multicolumn{2}{|c|}{$3-5$} & \multicolumn{2}{|c|}{$5-7$} & \multicolumn{2}{|c|}{$7-9$} & \multicolumn{2}{|c|}{$9-11$} & \multicolumn{2}{|c|}{$>11$} & & & & \\
\hline & A & B & A & B & A & B & A & B & A & B & A & B & A & B & A & B \\
\hline $\begin{array}{l}\text { CA18 } \\
\text { PVP1 }\end{array}$ & - & - & 0.50 & 1.21 & 0.91 & - & 0.09 & 0.10 & 1.08 & 1.31 & 1.79 & 2.25 & 4.37 & 4.87 & 5.89 & 6.50 \\
\hline $\begin{array}{l}\text { CA18 } \\
\text { PVP2 }\end{array}$ & - & - & 1.59 & 0.73 & - & - & 0.09 & - & 1.27 & 1.99 & 0.74 & 2.11 & 3.69 & 4.83 & 5.35 & 7.55 \\
\hline $\begin{array}{l}\text { CA18 } \\
\text { PVP3 }\end{array}$ & 0.16 & - & 1.32 & 1.56 & - & - & 0.12 & 0.10 & 1.27 & 1.23 & 1.13 & 1.25 & 4.00 & 4.14 & 5.63 & 6.82 \\
\hline $\begin{array}{l}\text { CA18 } \\
\text { PVP4 }\end{array}$ & - & - & 1.53 & 0.58 & - & 0.99 & 0.10 & 0.12 & 1.72 & 1.15 & 0.76 & 2.60 & 4.11 & 5.44 & 6.87 & 7.22 \\
\hline
\end{tabular}

A - before filtration, $\mathrm{B}$ - after filtration.

Table 3. Content of basic surface sites on investigated membranes before and after filtration with $20 \mathrm{mg} / \mathrm{L}$ iron solution [mmol/g]

\begin{tabular}{|c|c|c|c|c|c|c|c|c|c|c|c|c|c|c|}
\hline \multirow{3}{*}{ Membrane } & \multicolumn{10}{|c|}{$\mathrm{pH}$} & \multirow{2}{*}{\multicolumn{2}{|c|}{ Basic groups }} & \multirow{2}{*}{\multicolumn{2}{|c|}{ Oxygen-containing groups }} \\
\hline & \multicolumn{2}{|c|}{$3-5$} & \multicolumn{2}{|c|}{$5-7$} & \multicolumn{2}{|c|}{$7-9$} & \multicolumn{2}{|c|}{$9-11$} & \multicolumn{2}{|c|}{$>11$} & & & & \\
\hline & $A$ & B & $A$ & B & $A$ & B & $A$ & $B$ & $A$ & $B$ & $A$ & $B$ & A & $B$ \\
\hline CA18 PVP1 & - & - & 0.19 & 0.17 & - & 1.28 & 1.33 & 0.18 & $\begin{array}{ll}- \\
-\end{array}$ & - & 1.52 & 1.63 & 5.89 & 6.50 \\
\hline CA18 PVP2 & - & 1.18 & 0.19 & 0.19 & 1.24 & - & 0.23 & 1.35 & - & - & 1.66 & 2.72 & 5.35 & 7.55 \\
\hline CA18 PVP3 & - & 1.15 & 0.18 & 0.18 & 1.45 & 1.15 & - & 0.20 & - & - & 1.63 & 2.68 & 5.63 & 6.82 \\
\hline CA18 PVP4 & 1.13 & $\begin{array}{lll}- \\
\end{array}$ & 0.20 & 0.21 & 1.24 & 1.36 & 0.19 & 0.21 & $\begin{array}{lll}- & \\
\end{array}$ & - & 2.76 & 1.78 & 6.87 & 7.22 \\
\hline
\end{tabular}

$A$ - before filtration, $B$ - after filtration.

branes studied before and after the filtration of $\mathrm{Fe}^{3+}$ ion solution of the concentration $20 \mathrm{mg} / \mathrm{l}$.

Prior to filtration, the highest amount of acidic oxygen-containing groups $(4.37 \mathrm{mmol} / \mathrm{g})$ was found on the membrane with the lowest content of PVP. Somewhat lower values were obtained for membranes CA18 PVP3 and CA18 PVP4, 4.00 and $4.11 \mathrm{mmol} / \mathrm{g}$, respectively. The lowest amount of such groups, of $3.69 \mathrm{mmol} / \mathrm{g}$, was on the surface of the membrane containing $2 \mathrm{wt} . \%$ of PVP. The highest amount of basic oxygen functional groups before filtration was $2.76 \mathrm{mmol} / \mathrm{g}$ on the surface of the membrane with the greatest content of PVP. The contents of these groups on the other membranes were much smaller and equal to $1.52,1.66$ and $1.63 \mathrm{mmol} / \mathrm{g}$.

After the filtrations of iron ion solutions, the amount of acidic oxygen-containing groups increased on the surfaces of all membranes. The highest amount of acidic oxygen-containing groups of $5.44 \mathrm{mmol} / \mathrm{g}$, was noted for the membrane of the highest content of PVP. For membrane CA18 PVP1 after the filtration the amount of acidic surface oxygen-containing functional groups was smaller, $4.87 \mathrm{mmol} / \mathrm{g}$ and a similar value was obtained for CA18PVP2. The lowest content of these groups after filtration was on the surface of CA18 PVP3.

The highest number of acidic oxygen-containing groups after filtration occurs for the $\mathrm{pH}$ range above 11 . In this $\mathrm{pH}$ range, the amount of acidic groups increased significantly for all membranes from the CA18 series. The highest amount of acidic oxygen- containing sites of $2.60 \mathrm{mmol} / \mathrm{g}$ was determined for CA18PVP4, (with $4 \%$ content of PVP). The amounts of acidic oxygen-containing groups in the range $\mathrm{pH}=3-5$ decreased for membranes CA18PVP2 and CA18PVP4, while increased for CA18 PVP1 and CA18 PVP3. In this pH range, the contents of acidic oxygen-containing groups on the surfaces of membranes with 1 and $3 \%$ of PVP are 1.21 and $1.56 \mathrm{mmol} / \mathrm{g}$, respectively, while on the membranes containing 2 and $4 \%$ of PVP the corresponding values are $0.73 \mathrm{mmol} / \mathrm{g}$ and $0.58 \mathrm{mmol} / \mathrm{g}$, respectively. For membrane C18PVP4, the acidic oxygen-containing groups appeared in the $\mathrm{pH}$ range 5-7. For membrane CA18 PVP1 observed increase caused a disappearance of acidic oxygen-containing group from the $\mathrm{pH}$ range 5-7. For membranes CA18PVP1 and CA18PVP2, the number of acidic oxygen-containing groups increased for $\mathrm{pH}=$ 9-11, while for membrane CA18 PVP4 it decreased in this $\mathrm{pH}$ range. Similarly as for the membranes with $14 \%$ content of CA, also for the CA18 series after filtration, no acidic groups were detected below $\mathrm{pH}=3$.

The amount of basic oxygen-containing surface sites after the filtration of $\mathrm{Fe}^{3+}$ ions solution increased for membranes with 1, 2 and 3 wt.\% of PVP, while for membrane CA18PVP4 it decreased. The highest increase in the amount of basic oxygen-containing groups was observed for membranes CA18PVP2 and CA18PVP3. For these samples after the filtration the basic groups appeared in the $\mathrm{pH}$ range 3-5. Only for membrane CA18PVP2, the basic groups in the $\mathrm{pH}$ range 7-9 disappeared, while their number significantly increased in the $\mathrm{pH}$ range 9-11. For membrane CA18PVP3 a small decrease in the number of basic oxygen-containing groups was noted for $\mathrm{pH}=7-9$, while for $\mathrm{pH}=9-11$ a small number of basic oxygen-containing groups appeared. For membrane CA18PVP1, the number of basic oxygen-containing groups decreased in the $\mathrm{pH}$ range 9-11, but the basic groups appeared in the $\mathrm{pH}$ range $7-9$. For membrane CA18PVP4, the basic oxygen-containing groups in the $\mathrm{pH}$ range 3-5 disappeared. After filtration of iron ion solutions, in the extreme $\mathrm{pH}$ ranges, below 3 and above 11, no presence of basic oxygen-containing groups was detected.

Tables 4 and 5 present the data on the contents of acidic and basic oxygen-containing groups on the series of membranes studied before and after the filtration of copper ions solution of the concentration $1000 \mathrm{mg} / \mathrm{L}$.

The total amount of acidic oxygen-containing surface groups after the filtration was the highest for membranes with 2 and 3 wt.\% of PVP and equal to 5.16 and 5.67 $\mathrm{mmol} / \mathrm{g}$, respectively. For membranes CA14 PVP1 and CA14 PVP4, this amount was lower than $5 \mathrm{mmol} / \mathrm{g}$, 
Table 4. Content of acidic surface sites on investigated membranes before and after filtration with $1000 \mathrm{mg} / \mathrm{L}$ copper solution $[\mathrm{mmol} / \mathrm{g}$ ]

\begin{tabular}{|c|c|c|c|c|c|c|c|c|c|c|c|c|c|c|c|c|}
\hline \multirow{2}{*}{ Membrane } & \multicolumn{12}{|c|}{$\mathrm{pH}$} & \multicolumn{2}{|c|}{$\begin{array}{l}\text { Acidic } \\
\text { groups }\end{array}$} & \multicolumn{2}{|c|}{$\begin{array}{l}\text { Oxygen-containing } \\
\text { groups }\end{array}$} \\
\hline & $A$ & $\mathrm{~B}$ & $\mathrm{~A}$ & B & $A$ & B & $A$ & B & $A$ & B & $A$ & B & $A$ & $B$ & $A$ & $B$ \\
\hline $\begin{array}{l}\text { CA18 } \\
\text { PVP1 }\end{array}$ & - & - & 0.50 & 1.42 & 0.91 & - & 0.09 & 0.11 & 1.08 & 1.57 & 1.79 & 1.01 & 4.37 & 4.11 & 5.89 & 5.84 \\
\hline $\begin{array}{l}\text { CA18 } \\
\text { PVP2 }\end{array}$ & - & - & 1.59 & 1.57 & - & - & 0.09 & 0.11 & 1.27 & 1.19 & 0.74 & 2.29 & 3.69 & 5.16 & 5.35 & 6.72 \\
\hline $\begin{array}{l}\text { CA18 } \\
\text { PVP3 }\end{array}$ & 0.16 & - & 1.32 & 0.59 & - & - & 0.12 & 1.10 & 1.27 & - & 1.13 & 3.98 & 4.00 & 5.67 & 5.63 & 8.34 \\
\hline $\begin{array}{l}\text { CA18 } \\
\text { PVP4 }\end{array}$ & - & - & 1.53 & 0.59 & - & 0.91 & 0.10 & 0.12 & 1.72 & 1.30 & 0.76 & 1.64 & 4.11 & 4.56 & 6.87 & 6.18 \\
\hline
\end{tabular}

A - before filtration, $\mathrm{B}-$ after filtration.

Table 5. Content of basic surface sites on investigated membranes before and after filtration with $1000 \mathrm{mg} / \mathrm{L} \mathrm{copper} \mathrm{solution}$ $[\mathrm{mmol} / \mathrm{g}]$

\begin{tabular}{|c|c|c|c|c|c|c|c|c|c|c|c|c|c|c|}
\hline \multirow{3}{*}{ Membrane } & \multicolumn{10}{|c|}{$\mathrm{pH}$} & \multirow{2}{*}{\multicolumn{2}{|c|}{ Basic groups }} & \multirow{2}{*}{\multicolumn{2}{|c|}{$\begin{array}{l}\text { Oxygen- } \\
\text {-containing } \\
\text { groups }\end{array}$}} \\
\hline & \multicolumn{2}{|c|}{$3-5$} & \multicolumn{2}{|c|}{$5-7$} & \multicolumn{2}{|c|}{ 7-9 } & \multicolumn{2}{|c|}{$9-11$} & \multicolumn{2}{|c|}{$>11$} & & & & \\
\hline & A & B & A & $B$ & $A$ & B & A & B & $A$ & B & A & B & $A$ & B \\
\hline $\begin{array}{l}\text { CA18 } \\
\text { PVP1 }\end{array}$ & - & - & 0.19 & 0.20 & - & 1.17 & 1.33 & 0.36 & - & - & 1.52 & 1.73 & 5.89 & 5.84 \\
\hline $\begin{array}{l}\text { CA18 } \\
\text { PVP2 }\end{array}$ & - & - & 0.19 & 0.22 & 1.24 & 1.34 & 0.23 & - & - & - & 1.66 & 1.56 & 5.35 & 6.72 \\
\hline $\begin{array}{l}\text { CA18 } \\
\text { PVP3 }\end{array}$ & - & 1.08 & 0.18 & 0.19 & 1.45 & 1.24 & - & 0.16 & - & - & 1.63 & 2.67 & 5.63 & 8.34 \\
\hline $\begin{array}{l}\text { CA18 } \\
\text { PVP4 }\end{array}$ & 1.13 & - & 0.20 & 0.22 & 1.24 & - & 0.19 & 1.40 & - & - & 2.76 & 1.62 & 6.87 & 6.18 \\
\hline
\end{tabular}

A - before filtration, B - after filtration.

that is 4.11 and $4.56 \mathrm{mmol} / \mathrm{g}$. For the membrane of the lowest content of PVP, in the $\mathrm{pH}$ range $3-5$, the amount of acidic oxygen-containing groups increases, but they disappear in the next $\mathrm{pH}$ range ( $\mathrm{pH}$ 5-7). For CA18 PVP3 after the filtration, in the $\mathrm{pH}$ range $9-11$, the acidic oxygen-containing groups disappear and above 11 their amount significantly increases up to $3.98 \mathrm{mmol} / \mathrm{g}$. For the same membrane, in the $\mathrm{pH}$ range $3-5$ the amount of acidic oxygen-containing groups considerably decreases, although it decreases even more for CA18 PVP4. After the filtration of copper ions solution, on the surface of CA18 PVP4 the acidic groups appear in the $\mathrm{pH}$ range 5-7, while in the range 9-11 their content decreases. Above $\mathrm{pH} 11$, on the surface of membrane CA18 PVP4, the amount of acidic oxygen-containing groups increases from 0.76 to $1.64 \mathrm{mmol} / \mathrm{g}$. For $\mathrm{pH}$ below 3, no presence of acidic oxygen-containing groups was detected on the surface of all membranes.

After the filtration, the total amount of surface oxygen-containing groups of basic character decreases for CA18 membranes with 2 and $4 \%$ wt. of PVP, and the decrease in more pronounced for CA18 PVP4 from 2.76 to 1.62 $\mathrm{mmol} / \mathrm{g}$. For membranes CA18 PVP1 and CA18 PVP3 their amount increases. The greatest amount of basic oxygen-containing groups of $2.67 \mathrm{mmol} / \mathrm{g}$ was determined for membrane CA18PVP3. For membrane CA18 PVP4 a considerable number of basic oxygen-containing groups disappeared in the $\mathrm{pH}$ range 3-5 and 7-9. For CA18 PVP2 a small number of basic oxygen-containing groups disappeared in the $\mathrm{pH}$ range 9-11. For CA18 PVP3 after filtration a large number of basic oxygen-containing groups, close to $1.08 \mathrm{mmol} / \mathrm{g}$, appeared in the $\mathrm{pH}$ range $3-5$ and a small amount of about 0.16 $\mathrm{mmol} / \mathrm{g}$ appeared in the $\mathrm{pH}$ range $9-11$. For membrane CA18 PVP1, the presence of basic oxygen-containing groups on the surface in the number of $1.17 \mathrm{mmol} / \mathrm{g}$ was detected only after filtration in the pH range 7-9. For the same membrane, in the $\mathrm{pH}$ range 9-11, the amount of basic oxygen-containing groups decreased from 1.33 to $0.36 \mathrm{mmol} / \mathrm{g}$ after filtration. On the surface of membrane CA18 PVP4 the number of basic oxygen-containing groups increased from 0.19 to $1.40 \mathrm{mmol} / \mathrm{g}$. In the extreme ranges of $\mathrm{pH}$, below 3 and above 11, no presence of basic oxygen-containing groups was found.

Figure 1 presents value of determined before and after the filtration of $\mathrm{Fe}^{3+}$ ions solutions.

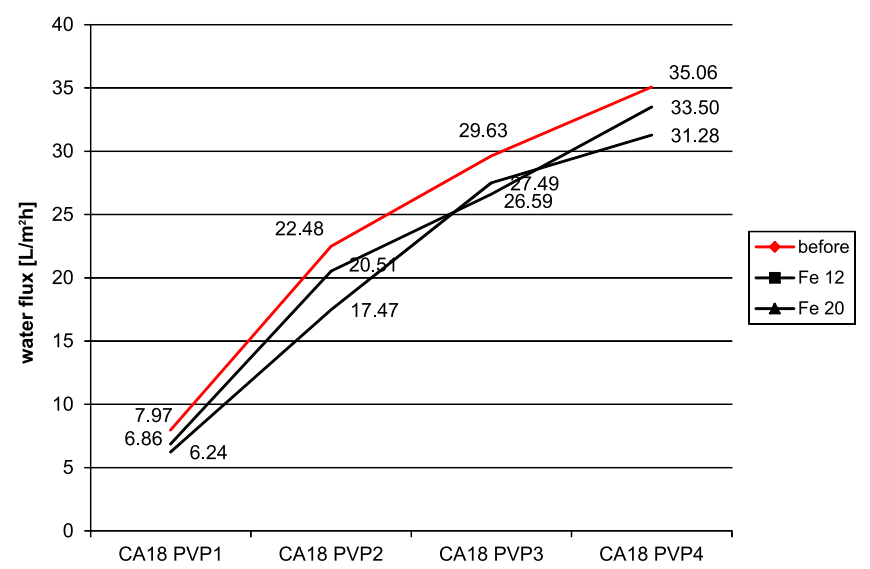

Figure 1. Metal ions removal by polymer membranes obtained on the basis of cellulose acetate

For all membranes, water flux increase with increasing content of the cross-linker agent. For membrane CA18 PVP1 before filtrations water flux was $7.97 \mathrm{~L} / \mathrm{m}^{2} \mathrm{~h}$, while for CA18PVP4 the value increases to $35.06 \mathrm{~L} / \mathrm{m}^{2} \mathrm{~h}$. Irrespectively of the content of PVP in membrane, the value of water flux before filtrations are higher than after the processes, which is a result of membrane pore blocking. For the majority of membranes, the water flux were higher after the filtration of $\mathrm{Fe}^{3+}$ solution of the 
concentration $20 \mathrm{mg} / \mathrm{L}$ than those after the filtration of the solution of the concentration $12 \mathrm{mg} / \mathrm{L}$. Only for CA18 PVP3, the value of water flux was higher after the filtration of iron ions solution of the concentration 12 $\mathrm{mg} / \mathrm{L}$ than after the filtration of the solution of higher concentration.

Figure 2 presents the water flux values determined before and after the filtrations of $\mathrm{Cu}^{2+}$ ions solutions.

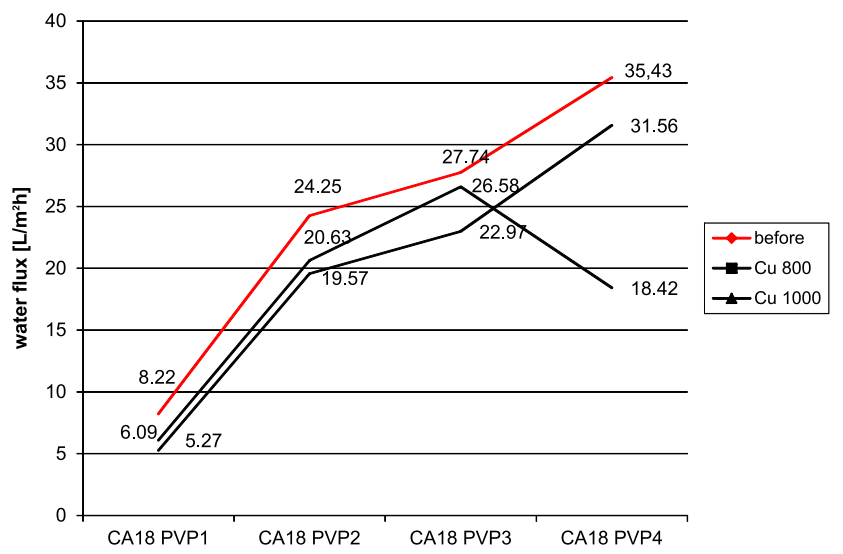

Figure 2. Metal ions removal by polymer membranes obtained on the basis of cellulose acetate

For all membranes, the values before filtration increase with increasing content of the PVP. The lowest value of $8.22 \mathrm{~L} / \mathrm{m}^{2} \mathrm{~h}$ was obtained for CA18 PVP1, while for CA18 PVP2, CA18 PVP3 and CAPVP4, the water flux were $24.25,27.74 \mathrm{~L} / \mathrm{m}^{2} \mathrm{~h}$ and $35.43 \mathrm{~L} / \mathrm{m}^{2} \mathrm{~h}$, respectively. The values of water flux after the filtration of copper ions solution of the concentration $1000 \mathrm{mg} / \mathrm{L}$ were for the majority of membranes higher than those obtained after the filtration of the solution of lower copper ions concentration. The only exception was CA18 PVP4 for which the water flux after the filtration of the copper solution of $1000 \mathrm{mg} / \mathrm{L}$ was much lower than that after the filtration of $800 \mathrm{mg} / \mathrm{L}$ solution. The higher value before than after the filtrations are a consequence of membrane pore blocking.

Figure 3 presents the abilities of CA18 series membranes to remove iron ions from liquid phase.

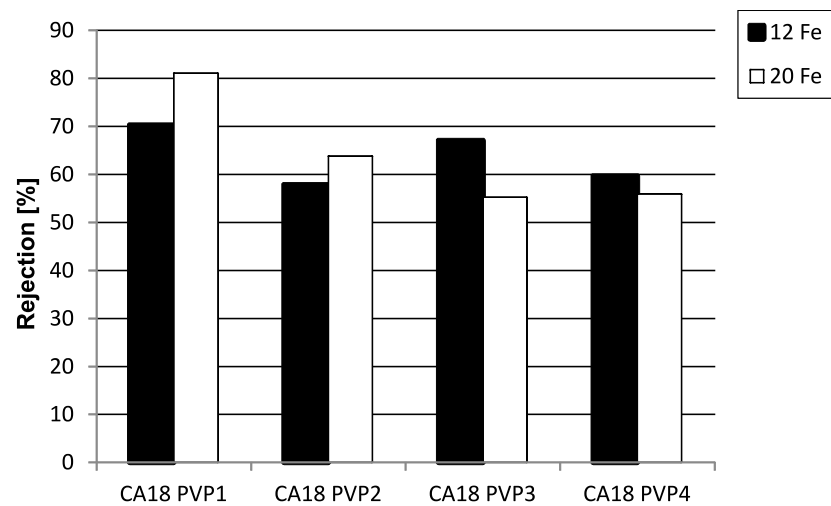

Figure 3. Metal ions removal by polymer membranes obtained on the basis of cellulose acetate

When the iron ions solution of $12 \mathrm{mg} / \mathrm{L}$ is used, the most effective in their removal, $70 \%$, shows membrane CA18PVP1, a slightly lower value of $67 \%$ is found for CA18 PVP3, while the values of rejection for the other two membranes are 57 and $59 \%$. After the filtration of iron solution of the concentration $20 \mathrm{mg} / \mathrm{L}$, the effecti- veness of iron ions removal decreased and this decrease was dependent on the PVP content. The highest value of R, of $81 \%$, was obtained for CA18 PVP1, while for CA18 PVP2 this value decreased to $64 \%$, and for the other two R was close to $55 \%$. According to the results presented, membranes CA18 PVP1 and CA18 PVP2 are more effective in removal of $\mathrm{Fe}^{3+}$ ions from the $20 \mathrm{mg} / \mathrm{L}$ solution than from the $12 \mathrm{mg} / \mathrm{L}$ one, while the reversed tendency is observed for membranes CA18PVP3 and CA18PVP4.

The degree of copper ions removal for the 4 membranes studied is shown in Figure 4. The values of $\mathrm{R}$ for membranes CA18 PVP1 and CA18 PVP2 after the filtration from copper solution of the concentration 800 $\mathrm{mg} / \mathrm{L}$ are similar and equal to 23 and $21 \%$. For membrane CA18PVP3 this value decreases to $10 \%$, while for CA18PVP4, rejection increases to $14 \%$. Completely divergent values were effectiveness of copper ions removal were obtained after the filtrations of the copper solution of $1000 \mathrm{mg} / \mathrm{L}$ concentration. The highest effectiveness in copper ions removal showed membrane CA18 PVP1 (29\%), while the effectiveness of CA18 PVP2 is $0.27 \%$ and CA18 PVP3 is $0.77 \%$. The effectiveness of copper ions removal from the solution of $1000 \mathrm{mg} / \mathrm{L}$ was $10 \%$ for CA18 PVP4.

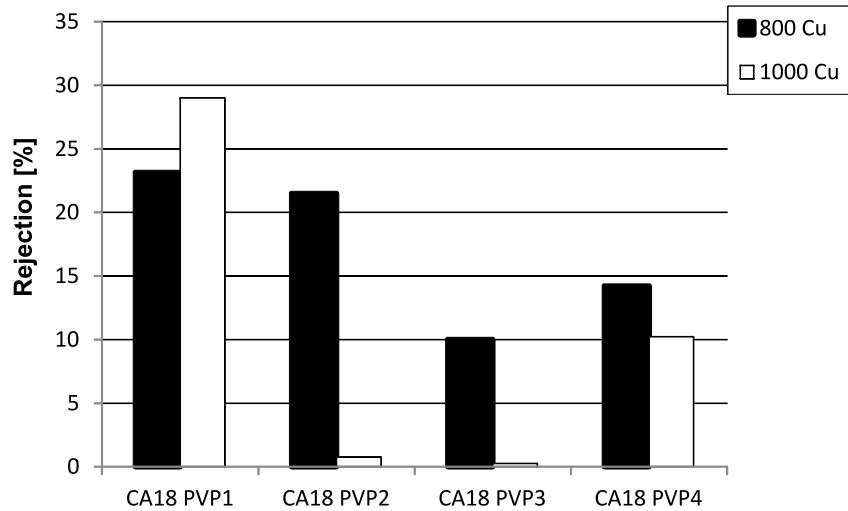

Figure 4. Metal ions removal by polymer membranes obtained on the basis of cellulose acetate

Figure 5 shows the flux recovery ratio (FRR) of the membranes studied for different solutions.

After the filtrations of iron ions solutions, the FRR value increased with increasing content of PVP. For membrane CA18 PVP1 the FRR value was $79 \%$, for CA18PVP2 it was 85\%, while for CA18 PVP3 and CA18 PVP4, the values of FRR were 91 and 93\%, respectively. After the filtrations of copper ions solutions, the FRR

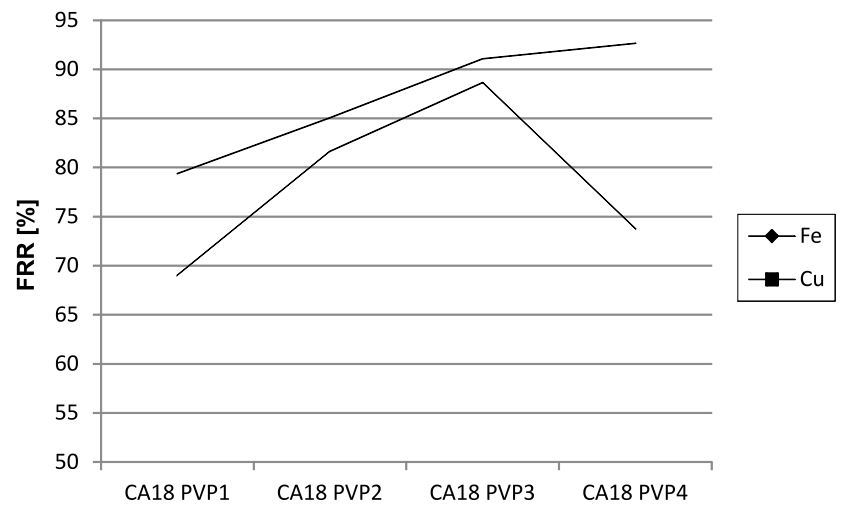

Figure 5. Metal ions removal by polymer membranes obtained on the basis of cellulose acetate 
values at first increase with increasing PVP content and reach $69 \%$ for CA18 PVP1, 82\% for CA18 PVP2 and $89 \%$ for CA18 PVP3, but significantly depart from this tendency for CA18PVP4, for which FRR is $74 \%$. For the first 3 membranes FRR increases with increasing PVP content in membrane.

The values of particular type resistances determined for the CA18 series membranes after the filtration of iron ions are collected in Table 6 .

Table 6. Filtration resistance of different membranes for iron solution

\begin{tabular}{|l|c|c|c|c|}
\hline Membrane & $\begin{array}{l}\text { CA18 } \\
\text { PVP1 }\end{array}$ & $\begin{array}{r}\text { CA18 } \\
\text { PVP2 }\end{array}$ & $\begin{array}{c}\text { CA18 } \\
\text { PVP3 }\end{array}$ & $\begin{array}{c}\text { CA18 } \\
\text { PVP4 }\end{array}$ \\
\hline $\mathrm{R}_{\mathrm{m}}\left(\times 10^{13}\right)$ & 13.40 & 5.45 & 2.91 & 3.52 \\
\hline $\mathrm{R}_{\mathrm{p}}\left(\times 10^{13}\right)$ & 16.60 & 6.06 & 3.17 & 3.71 \\
\hline $\mathrm{R}_{\mathrm{c}}\left(\times 10^{13}\right)$ & 16.80 & 5.54 & 2.99 & 3.48 \\
\hline $\mathrm{R}_{\mathrm{t}}\left(\times 10^{13}\right)$ & 46.80 & 17.05 & 9.07 & 10.71 \\
\hline
\end{tabular}

The highest value of total resistance $R_{t}$ of $46.80 \mathrm{x}$ $10^{13} \mathrm{~L} / \mathrm{m}^{2} \mathrm{~h}$ was determined for membrane CA18PVP1. The total resistance of CA18 PVP2 was much lower, of $17.05 \times 10^{13} \mathrm{~L} / \mathrm{m}^{2} \mathrm{~h}$, while for membranes CA18PVP3 and CA18PVP4 the total resistance was 9.07 and 10.71 $\mathrm{x} 10^{13} \mathrm{~L} / \mathrm{m}^{2} \mathrm{~h}$. The partial resistances for particular membranes change following the same tendency as the total resistance of filtration. The values of resistances determined after the filtrations of copper ions solutions are presented in Table 7.

Table 7. Filtration resistance of different membranes for copper solution

\begin{tabular}{|l|c|c|c|c|}
\hline Membrane & $\begin{array}{r}\text { CA18 } \\
\text { PVP1 }\end{array}$ & $\begin{array}{r}\text { CA18 } \\
\text { PVP2 }\end{array}$ & $\begin{array}{r}\text { CA18 } \\
\text { PVP3 }\end{array}$ & $\begin{array}{r}\text { CA18 } \\
\text { PVP4 }\end{array}$ \\
\hline $\mathrm{R}_{\mathrm{m}}\left(\times 10^{13}\right)$ & 15.60 & 3.69 & 3.63 & 2.33 \\
\hline $\mathrm{R}_{\mathrm{p}}\left(\times 10^{13}\right)$ & 22.70 & 4.21 & 3.79 & 3.69 \\
\hline $\mathrm{R}_{\mathrm{c}}\left(\times 10^{13}\right)$ & 26.30 & 3.86 & 3.42 & 4.58 \\
\hline $\mathrm{R}_{\mathrm{t}}\left(\times 10^{13}\right)$ & 64.60 & 11.76 & 10.84 & 10.60 \\
\hline
\end{tabular}

The highest value of $\mathrm{R}_{\mathrm{t}}$, reaching $64.60 \times 10^{13} \mathrm{~L} / \mathrm{m}^{2} \mathrm{~h}$ was obtained for CA18 PVP1 and is much different from the values obtained for the other membranes. The total resistance for the other membranes varied from $11.76 \times 10^{13} \mathrm{~L} / \mathrm{m}^{2} \mathrm{~h}$ for CA18PVP2 to $10.60 \times 10^{13} \mathrm{~L} /$ $\mathrm{m}^{2} \mathrm{~h}$ for CA18PVP4, so are similar, while the value for CA18PVP1 is a few times higher.

\section{CONCLUSIONS}

Depending on the content of PVP, the membranes from the series studied showed negligible different degrees of surface hydrophilicity. The content of PVP added had no effect on the membranes porosities and equilibrium water content. Before and after the filtrations, the dominant presence of acidic oxygen functional groups was established. For the majority of membranes the number of these groups increased after the processes of filtration. The permeability of membranes of cellulose acetate increased with increasing content of PVP, and decreased after the processes of filtration as a result of pore blocking. Irrespective of the solvent concentrations, the membranes studied were more effective in removal of $\mathrm{Fe}^{3+}$ ions than $\mathrm{Cu}^{2+}$ ions from liquid phase. After the filtrations of iron ions, the values of FRR were high and increased with increasing PVP content in the membranes. The membrane resistance decreased with increasing PVP content.

\section{LITERATURE CITED}

1. Zorita, I., Apraiz, I., Ortiz-Zarragoitia, M., Orbea, A., Cancio, I., Soto, M., Marigomez, I. \& Cajaraville, M.P. (2007). Assessment of biological effects of environmental pollution along the NW Mediterranean Sea using mussels as sentinel organisms. Environ. Pollut. 148, 236-250. DOI: 10.1016/j. envpol.2006.10.022.

2. Guo, G., Wu, F., Xie, F. \& Zhang, R. (2012). Spatial distribution and pollution assessment of heavy metals in urban soils from southwest China. J. Environ. Sci. 24(3), 410-418. DOI: 10.1016/S1001-0742(11)60762-6.

3. Seinfeld, J.H. \& Pandis, S.N. (2006). Atmospheric Chemistry and Physic (2nd ed.). New Jersey, USA: John Wiley \& Sons.

4. Lewis, M. \& Pryor, R. (2013). Toxicities of oils, dispersants and dispersed oils to algae and aquatic plants: Review and database value to resource sustainability. Environ. Pollut. 180, 345-367. DOI: 10.1016/j.envpol.2013.05.001.

5. Camargo, J.A. \& Alonso, A. (2006). Ecological and toxicological effects of inorganic nitrogen pollution in aquatic ecosystems: A global assessment. Environ. Int. 32, 831-849. DOI: 10.1016/j.envint.2006.05.002.

6. Khan, S., Shahnaz, M., Jehan, N., Rehman, S., Shah, M. T. \& Din, I. (2013). Drinking water quality and human health risk in Charsadda district, Pakistan. J. Clean. Prod. 60, 93-101. DOI: $10.1016 /$ j.jclepro.2012.02.016.

7. Ostolska, I. \& Wiśniewska, M. (2015). Investigation of the colloidal $\mathrm{Cr}_{2} \mathrm{O}_{3}$ removal possibilities from aqueous solution using the ionic polyamino acid block copolymers. J. Hazard. Mater. 290, 69-77. DOI: 10.1016/j.jhazmat.2015.02.068.

8. Wiśniewska, M., Nosal-Wiercińska, A., Dąbrowska, I. \& Szewczuk-Karpisz, K. (2013). Effect of the solid pore size on the structure of polymer film at the metal oxide/polyacrylic acid solution interface - Temperature impact. Micropor. Mesopor. Mater. 175, 92-98. DOI: 10.1016/j.micromeso.2013.03.032.

9. Wiśniewska, M., Ostolska, I., Szewczuk-Karpisz, K. \& Nosal-Wiercińska, A. (2015). Adsorption and Stability Properties of Aqueous Suspension of Chromium (III) Oxide in the Presence of Synthetic and Natural Polymers: Possibilities of Solid Removal. Adsorpt. Sci. Technol. 33, 639-700. DOI: 10.1260/0263-6174.33.6-8.693.

10. Nowicki, P., Kazmierczak-Razna, J. \& Pietrzak, R. (2016). Physicochemical and adsorption properties of carbonaceous sorbents prepared by activation of tropical fruit skins with potassium carbonate. Mater. Design. 90, 579-585. DOI: 10.1016/j. matdes.2015.11.004.

11. Nowicki, P., Bazan, A., Kazmierczak-Razna, J. \& Pietrzak, R. (2015). Sorption Properties of Carbonaceous Adsorbents Obtained by Pyrolysis and Activation of Pistachio Nut Shells. Adsorpt. Sci. Technol. 33(6-8), 581-586. DOI: 10.1260/02636174.33.6-8.581.

12. Nowicki, P., Supłat, M., Przepiórski, J. \& Pietrzak, R. (2012). $\mathrm{NO}_{2}$ removal on adsorbents obtained by pyrolysis and physical activation of cardboard. Chem. Eng. J. 195-196, 7-14. DOI: 10.1007/s10450-015-9729-x. DOI: 10.1016/j.cej.2012.04.073.

13. Nowicki, P., Szymanowski, W. \& Pietrzak, R. (2015). Textural, surface, thermal and sorption properties of the functionalized activated carbons and carbon nanotubes. Pol. $J$. Chem. Technol. 17(4), 120-127. DOI: 10.1515/pjct-2015-0078.

14. Jasiewicz, K. \& Pietrzak, R. (2013). The influence of pore generating agent on the efficiency of copper and iron ions removal from liquid phase by polyethersulfone membranes. Chem. Eng. J. 228, 449-454. DOI: 10.1016/j.cej.2013.05.005.

15. Wei, P., Zhang, K., Gao, W., Kong, L. \& Field, R. (2013). CFD modeling of hydrodynamics characteristics of slug bubble flow in a flat sheet membrane bioreactor. J. Membr. Sci. 445, 15-24. DOI: 10.1016/j.memsci.2013.05.036.

16. Matos, M., Suarez, M.A., Gutierrez, G., Coca, J. \& Pazos, C. (2013). Emulsification with microfiltration ceramic membra- 
nes: A different approach to droplet formation mechanism. $J$. Membr. Sci. 444, 345-358. DOI: 10.1016/j.memsci.2013.05.033.

17. Han, J., Cho, Y.H., Kong, H., Han, S. \& Park, H.B. (2013). Preparation and characterization of novel acetylated cellulose ether (ACE) membranes for desalination applications. J. Membr. Sci. 428, 533-545. DOI: 10.1016/j.memsci.2012.10.043.

18. Qdais, H.A. \& Moussa, H. (2004). Removal of heavy metals from wastewater by membrane processes: a comparative study. Desalination 164, 105-110. DOI: 10.1016/S00119164(04)00169-9.

19. Lee, K.J., Mower, R., Hollenbeck, T., Castelo, J., Johnson, N., Gordon, P., Sinko P.J., Holme, K. \& Lee, Y.H. (2003). Modulation of Nonspecific Binding in Ultrafiltration Protein Binding Studies. PHrm. Res. 7, 1015-1021. DOI: 10.1023/A:1024406221962.

20. Lobo, A., Cambiella, A., Benito, J.M., Pazos, C. \& Coca, J. (2006). Ultrafiltration of oil-in-water emulsions with ceramic membranes: Influence of $\mathrm{pH}$ and crossflow velocity. J. Membr. Sci. 278, 328-334. DOI: 10.1016/j.memsci.2005.11.016.

21. Purkait, M.K., DasGupta, S. \& De, S. (2004). Removal of dye from wastewater using mecellar-enhanced ultrafiltration and recovery of surfactant. Sep. Purif. Technol. 37, 81-92. DOI: 10.1016/j.seppur.2003.08.005.

22. Zarębska, A. et al. Anna Narębska, Piotr Adamczak, Stanisław Koter, Wojciech Kujawski, Andrzej Warszawski, Marek Staniszewski, Grzegorz Sionkowski (1997). Membrany $i$ membranowe techniki rozdziatu (in Polish). Toruń, Polska: Wydaw. UMK.

23. Hendrix, K., Vaneynde, M., Koeckelberghs, G. \& Vankelecom, I.F.J. (2013). Synthesis of modified poly(ether ether ketone) polymer for the preparation of ultrafiltration and nanofiltration membranes via phase inversion. J. Membr. Sci. 447, 96-106. DOI: 10.1016/j.memsci.2013.07.006.

24. Wu, Z., Faiz, R., Li, T., Kingsbury, B.F.K. \& Li, K. (2013). A controlled sintering process for more permeable ceramic hollow fibre membranes. J. Membr. Sci. 446, 286-293. DOI: 10.1016/j.memsci.2013.05.040.

25. Tabatabaei, S.H., Carreau, P.J. \& Ajji, A. (2009). Microporous membranes obtained from PP/HDPE multilayer films by stretching. J. Membr. Sci. 345, 148-159. DOI: 10.1016/j. memsci.2009.08.038.

26. Li, N., Xiao, C., An, S. \& Hu, X. (2010). Preparation and properties of PVDF/PVA hollow fiber membranes. Desalination 250, 530-537. DOI: 10.1016/j.desal.2008.10.027.

27. Rahimpour, A., Madaeni, S.S. \& Mansourpanah, Y. (2010). Nano-porous polyethersulfone (PES) membranes modified by acrylic acid (AA) and 2-hydroxyethylmethacrylate (HEMA) as additives in gelation media. J. Membr. Sci. 364, 380-388. DOI: 10.1016/j.memsci.2010.08.046.

28. Lalia, B.S., Kochkodan, V., Hashaikeh, R. \& Hilah, N. (2013). A review on membrane fabrication: Structure, properties and performance relationship. Desalination 326, 77-95. DOI: 10.1016/j.desal.2013.06.016.

29. Sairam, M., Sereewatthanawut, E., Li, K., Bismarck, A. \& Livingston, A.G. (2011). Method for the preparation of cellulose acetate flat sheet composite membranes for forward osmosis-Desalination using $\mathrm{MgSO}_{4}$ draw solution. Desalination 273, 299-307. DOI: 10.1016/j.desal.2011.01.050.

30. Hołda, A.K., Aernouts, B., Saeys, W. \& Vankelecom, I.F.J. (2013) Study of polymer concentration and evaporation time as phase inversion parameters for polysulfone-based SRNF membranes. J. Membr. Sci. 442, 196-205. DOI: 10.1016/j. memsci.2013.04.017.

31. Cao, J.H., Zhu, B.K., Ji, G.L. \& Xu, Y.Y. (2005). Preparation and characterization of PVDF-HFP microporous flat membranes by supercritical $\mathrm{CO}_{2}$ induced phase separation. $J$. Membr. Sci. 266, 102-109. DOI: 10.1016/j.memsci.2005.05.015.

32. Ren, J., Zhou, J. \& Deng, M. (2010). Morphology transition of asymmetric flat sheet and thickness-gradient membranes by wet phase-inversion process. Desalination 253, 1-8. DOI: 10.1016/j.desal.2009.12.001.

33. Foy, S.P. \& Labhasetwar, V. (2011). Oh the irony: Iron as a cancer cause or cure? Biomaterials 32, 9155-9158. DOI: 10.1016/j.biomaterials.2011.09.047.

34. Walter, U. (2010). Transcranial Sonography in Brain Disorders with Trace Metal Accumulation. Int. Rev. Neurobiol. 90, 166-178. DOI: 10.1016/S0074-7742(10)90012-3.

35. Kang, Y.J. (2011). Copper and homocysteine in cardiovascular diseases. PHrmacol. Ther. 129, 321-331. DOI: 10.1016/j. pHrmthera.2010.11.004.

36. Rines, A.K. \& Ardehali, H. (2013). Transition metals and mitochondrial metabolism in the heart. J. Mol. Cell. Cardiol. 55, 50-57. DOI: 10.1016/j.yjmcc.2012.05.014.

37. Hofman, M. \& Pietrzak, R. (2011). Adsorbents obtained from waste tires for $\mathrm{NO}_{2}$ removal under dry conditions at room temperature. Chem. Eng. J. 170, 202-208. DOI: 10.1016/j. cej.2011.03.054.

38. Li, N. N., Fane, A.G., Winston, Ho, W.S. \& Matsuura, T. (2008). Advanced membrane technology and applications. New Jersey, USA: John Wiley \& Sons.

39. Basile, A. \& Gallucci, F. (2011). Membranes for Membrane Reactors. Preparation, Optimalization and Selection. Chichester, UK: John Wiley \& Sons. 